\title{
A comparative study of cellulase production in inorganic and organic supplements by a cellulolytic tree bark fungus
}

\author{
Vijeetha Vijayan \& A Jayakumaran Nair* \\ Department of Biotechnology, University of Kerala, Thiruvananthapuram, Kerala, India \\ *Email: jekksnair@gmail.com
}

\section{ARTICLE HISTORY}

Received: 23 December 2019

Accepted: 02 March 2020

Published: 01 May 2020

\section{KEYWORDS}

cellulase

inorganic supplements

organic supplements

sugarcane bagasse

\begin{abstract}
The study was conducted to compare the cellulase production using organic and inorganic supplements by isolating a tree bark (Mangifera indica) fungus, for a cost-effective cellulase production. Three fungi $\left(f_{1}, f_{2}\right.$ and $\left.f_{3}\right)$ were isolated from the bark of the tree, of which $f_{3}$ was found to be potential in cellulase production which was confirmed by primary screening (congo red activity staining). Through endoglucanase and total cellulase activity assays, it was observed that the isolated strain exhibited cellulase activity of $0.25 \mathrm{U} / \mathrm{ml}$ for endoglucanase when $1 \% \mathrm{CMC}$ was supplemented to the medium. An activity of $8 \mathrm{IU} / \mathrm{g}$ towards FPase and for endoglucanase $10.35 \mathrm{U} / \mathrm{g}$ was obtained on non-purified inorganic supplements. Sugarcane bagasse was found to be the best inorganic supplement for cellulase production. Here, we try to adopt a cost-effective production strategy of cellulase. The future perspective of this investigation is to identify the strain and purification of the enzyme for industrial purpose.
\end{abstract}

\section{Introduction}

Cellulose is the major constituent of the plant cell wall. It is the most abundant organic compound found on earth surface $(1,2)$. Plants produce $1.5 \times 10^{12}$ tons of cellulose annually which is a highly stable crystalline polymer consisting of $\beta-1,4$-linked glycosyl residues, along other polysaccharides (3). Accordingly, with this bulk production, its turnover in the carbon cycle is also of great importance. Degradation of cellulose could be achieved mainly in two ways, one by chemical means and the other by enzymatic method. Acid treatment may result in various undesirable end products. Moreover, the hydrolysate, glucose from cellulose is only $33 \%$ since the conversion of glucose from cellulose and the formation of side products from glucose occurs at the same rate. The conversion of cellulose to glucose achieved through enzymatic hydrolysis is preferred over chemical methods (4).

Cellulase are group of enzymes comprising of endoglucanase-EG (EC 3.2.1.4), cellobiohydrolase-CBH, EC 3.2.1.91 and $\beta$-glucosidase EC 3.2.1.21; which together contribute the breakdown of $\beta-1,4-D$ glucosidic bonds in the cellulose (5). Due to wide range of applications its spectrum has expanded in various industries including food, textiles, laundry, pulp, paper, agriculture, bioprocess, bio-energy as well as in research and development (6-8). In combination with other enzymes, viz., protease, amylase, lipase and laccase, modern-type heavy-duty detergents contain cellulase to increase their effectiveness as detergents. Cellulases added to laundry detergents improve the softness, colour brightness, bio-polishing and dirt removal from cotton blended garments $(9,10-12)$. The burning of fossil fuels is a major concern with respect to global climate change. Uncertain petroleum sources and the rising cost of fuel are yet other issues. These concerns have shifted to utilize renewable resources for the production of a 'greener' energy replacement which can meet the high energy demand of the world (13).

Main producers of cellulase are microorganisms including fungi, bacteria and some species of actinomycetes (14). Filamentous fungi are excellent producers of enzymes, they produce enzymes extracellularly. Glucoamylase, cellulase, lipase, glucose-oxidase, pectinase, laccase, catalase, phytase and proteases are some of the enzymes produced by

(c) Vijeetha \& Nair (2020). This is an open-access article distributed under the terms of the Creative Commons Attribution License, which permits unrestricted use, distribution, and reproduction in any medium, provided the original author and source are credited (https://creativecommons.org/licenses/by/4.0/).

To cite this article: Vijeetha V, Nair AJ. A comparative study of cellulase production in inorganic and organic supplements by a cellulolytic tree bark fungus. Plant Science Today. 2020;7(2):227-232. https://doi.org/10.14719/pst.2020.7.2.708 
filamentous fungi. The increasing demand for energy and the depletion of the fossil fuel reserve urge us to find alternative energy resources such as biofuels. Besides all these benefits of the microbial enzyme, the cost of production is the main limitation. Use of agricultural raw materials and other unused cellulosic biomass as organic substrate could reduce the cost of production to an extent. Cellulosic biomass, derived from non-food sources, such as trees and grasses, is being explored as a feedstock for cellulosic ethanol production (15). Some researchers (16) have produced cellulase by using Kinnow pulp as substrate.

The study describes the role of fungal cellulase in the bioconversion of various agricultural residues which could be a solution to the serious issue relating the waste management. Cellulosic biomass contributes to municipal solid waste (MSW) deposition. Substituting organic substrates with inorganic biomass for the production of value-added products is a remedy for such solid waste disposal. As enzyme production is expensive, we can meet the cost of production by supplying inorganic supplements that could produce high enzyme titers. The major demands for enzymes in Indian industry is in Pharmaceutical sector followed by food industry, detergent (20\%) and textile industries. These demands are being satisfied by importing $70 \%$ of the total enzyme consumption. As enzyme production is expensive, we can meet the cost of production by supplying inorganic supplements that could produce high enzyme titers. The study demands the large scale production of cellulase which may help in stabilizing the country's economic status.

\section{Materials and Methods}

\section{Isolation of fungus}

The samples were isolated from tree bark near Meenachil river belts in Kottayam, Kerala. Isolation was done according to Saithong et al. (17) with modifications. The outer tree bark was separated using a sterile scalpel blade. The separated wooden pieces were cut in to small pieces. They were surface sterilized using $70 \%$ ethanol. Sterilised wooden pieces were transferred to sterile distilled water containing ampicillin $(30 \mu \mathrm{g} / \mathrm{ml})$ and shaken at an rpm of 100 for $48 \mathrm{hr}$. From each wooden piece, a loop full was inoculated on Sabourad dextrose agar (SDA) for fungal growth. The hyphal tip was aseptically taken and plated on to another SDA plate for purity. The fully grown strains were maintained on SDA at low temperature $\left(4 \pm 1^{\circ} \mathrm{C}\right)$.

\section{Screening for cellulase production}

The agar plates containing Carboxymethylcellulose (CMC) as carbon source was prepared and allowed to solidify. On the solidified CMC agar plates organism was point inoculated at the centre. The plates were sealed carefully with parafilm and kept for incubation overnight at $37^{\circ} \mathrm{C}$. After incubation, the plates were flooded with $0.1 \% \mathrm{w} / \mathrm{v}$ aqueous Congo red staining solution and kept for 15-20 min for incubation. After incubation, poured off the stain, a first wash was given by double distilled water and the plate was flooded with $1 \mathrm{M} \mathrm{NaCl}$. Poured off the destain and the process repeated 2-3 times $(18,19)$.

\section{Growth and maintenance of the isolate}

The fungal isolate was inoculated in SDA on sterile plates and incubated at $30{ }^{\circ} \mathrm{C}$. Subculturing was done every $15 \mathrm{~d}$ intervals. Agar slants were prepared for maintaining the culture and the fully grown slants were kept at $4{ }^{\circ} \mathrm{C}$. Agar blocks $(6 \mathrm{~mm})$ with mycelium were used as inoculum and were inoculated in sabouraud dextrose broth (SDB). The broth was incubated at room temperature $(30 \pm 2$ $\left.{ }^{\circ} \mathrm{C}\right)$. Growth was monitored routinely.

\section{Optimisation of Basal mineral salt media (BSM)}

The isolated strain was cultured in the Basal mineral Salt Medium (BSM). The selection of BSM should be in such a way that it should support the growth of the strain, and also should support the maximum production of the desired product regardless of secondary or primary metabolite.

Three media were considered for the study such as Vogel's medium, Fries medium and Bird medium. Inoculums (1\%) was aseptically transferred to the sterilized medium separately kept in a rotary shaker (Orbitek) at $100 \mathrm{rpm}$ and a temperature of $28{ }^{\circ} \mathrm{C}$. The media with the organism was allowed to grow. The activity was measured at every $24 \mathrm{hr}$ of incubation.

\section{Cellulase production by inorganic suppleme- ntation (SMF)}

For enzyme extraction, submerged fermentation was carried out by using BSM, where CMC, starch, lactose and sucrose act as major carbon sources $(1 \%$ each). The composition of BSM (g/l) was prepared by supplementing ammonium tartrate - $10 \mathrm{~g}, \mathrm{NH}_{4} \mathrm{NO}_{3}$ $2 \mathrm{~g}, \mathrm{KH}_{2} \mathrm{PO}_{4-} 2 \mathrm{~g}, \mathrm{MgSO}_{4} 7 \mathrm{H}_{2} \mathrm{O}-1 \mathrm{~g}, \mathrm{NaCl}-1 \mathrm{~g}, \mathrm{CaCl}_{2}$ $0.2 \mathrm{~g}$, trace elements $-200 \mu \mathrm{l}$, biotin stock - $100 \mu \mathrm{l}$ (6.1 $\mathrm{mg}$ of biotin in $100 \mathrm{ml}$ double distilled water; solubility adjusted by $1 \mathrm{~N} \mathrm{NaoH}$ ). The basal medium was used throughout the study. The fungal cultures from SDA slants were harvested aseptically by adding sterile water $(2 \mathrm{ml})$ and shaken for sometime so as to get a suspension of spores which was used for inoculation. The optimum time for enzyme production was then quantified.

\section{Cellulase production by organic supplementation (SSF)}

Natural and feasible substrates were selected for the studies which were obtained from the local market, Thiruvananthapuram. Four Agricultural residues were considered for the study (rice bran (RB), wheat bran (WB), sugarcane bagasse (SCB) and coconut cake (CC)). Biochemically all the residues used were composed of lignin, cellulose and hemicelluloses. All the substrates were dried under the sun and milled to a size of $6-8 \mathrm{~mm}$ particle, stored in airtight containers for further use.

SSF (Solid State Fermentation) carried out by autoclaving $5 \mathrm{~g}$ of substrates at $121{ }^{\circ} \mathrm{C}$ for $30 \mathrm{~min}$. Sterilized substrates were moistened with BSM (10 ml) and inoculated with $2 \%$ of spore suspension 
and kept for incubation for proper growth at $37{ }^{\circ} \mathrm{C}$ for $96 \mathrm{hr}$. Crude enzyme extract was prepared by the addition of $0.5 \mathrm{M}$ citrate buffer ( $\mathrm{pH} 4.5)$ to the fermented slurry. For adequate mixing, the mixture was kept in a shaker for $5 \mathrm{hr}$ at $120 \mathrm{rpm}$. A two-layered filtration was carried out using a muslin cloth and Whatman No.1 filter paper. The resultant cell-free, fermented liquid supernatant after centrifugation at $10000 \mathrm{rpm}$ for $10 \mathrm{~min}$ was considered as crude enzyme extract for the study.

\section{Quantification of cellulase activity}

The quantification of cellulase was done according to Ghose (20). Endoglucanase (1,4- $\beta$ glucan-4glucanohydrolase, EC 3.2.1.4) or CMCase (Carboxymethylcellulose) and FPase (Filter paper cellulase) activities were determined using DNS (3, 5-dinitro salicylic acid) method. Both CMCase and Fpase were measured spectrophotometrically at $540 \mathrm{~nm}$.

\section{CMCase activity}

For the estimation of endoglucanase activity, the reaction mixture $(2.5 \mathrm{ml})$ consisted of $0.5 \mathrm{ml}$ of crude enzyme solution, $1 \mathrm{ml}$ of $0.1 \mathrm{M}$ citrate buffer $\mathrm{pH} 4.5$ and $1 \mathrm{ml}$ of $1 \%$ carboxymethyl cellulose (w/v) (CMC High viscosity) which was incubated at $50{ }^{\circ} \mathrm{C}$ for $30 \mathrm{~min}$ in a bacteriological water bath (Memmert). Finally, the reaction was terminated by adding 3,5, dinitro salicylic acid (DNS) reagent. The hydrolysis product was read as reducing sugar and the absorbance measured at $540 \mathrm{~nm}$ using spectrophotometer (UV-1700 pharmaSpec UV-Vis Spectrophotometer Shimadzu).

\section{FPase activity}

The reaction mixture for determining FPase consisted of filter paper strip $1.0 \times 6.0 \mathrm{~cm}$ (= $50 \mathrm{mg})$, $0.5 \mathrm{ml}$ of crude enzyme solution, $1 \mathrm{ml}$ of $0.1 \mathrm{M}$ citrate buffer $\mathrm{pH} 4.5$ and incubated at $50{ }^{\circ} \mathrm{C}$ for 60 min. The reaction was stopped by adding DNS reagent. The reducing sugar was quantified spectrophotometrically at $540 \mathrm{~nm}$. For all enzyme activities, one unit of enzyme activity was defined as the amount of enzyme releasing $1 \mu \mathrm{mol}$ of glucose per min of reaction. The enzyme activities were expressed in $\mathrm{IU} / \mathrm{ml}$.

\section{Results and Discussion}

\section{Isolation and identification of cellulase producing fungus}

In the present study, three morphologically distinct fungal strains named $f_{1}, f_{2}$ and $f_{3}$ were isolated from tree bark on SDA. As an exploration of fungus which could degrade cellulose to produce cellulase, we spread out our study towards the isolation of the fungus from woody materials. Surface sterilisation (using $70 \%$ alcohol) was done to establish a contaminant free culture. Some researchers (21) have done surface sterilisation using alcohol (80\%). After isolating the fungus it was cultured and maintained on SDA plates. The isolated strain was able to produce pigment (Fig. 1).

\section{Cellulolytic activity}

Of three fungus isolated, $f_{3}$ was capable of degrading cellulose which was inferred from the plate assay. It showed a zone of clearance around the colony inoculated on 1\% CMC-agar plate when flooded with $0.1 \%$ Congo red stain prepared in sterilised double-distilled water. Destaining was performed by $1 \mathrm{M} \mathrm{NaCl}$. Several washes were given for destaining to visualise the zone of hydrolysis (Fig. 2). Reports (22) were there supporting the same composition of Congo red stain preparation using distilled water. Congo red is a diazo compound which can be used for the identification of amyloid (23). Congo red has various advantages over dyes such as Calcoflour and other fluorescent dyes used for identification purposes such as they are easily available and low cost $(22,24)$.

Congo red hydrolysis requires sufficient amount of substrates as well as the organism with high cellulase activity (25). This indicates that the organism is a potent producer of cellulase, which can actively degrade cellulosic substrates.

\section{Optimisation of media}

For the production of cellulase, media was optimised. Three fungal culture media were selected for the determination of culture media which could enhance the production of cellulase enzyme. Fries medium was found as optimum for producing cellulase. It was able to produce an enzyme titer of $0.19 \mathrm{U} / \mathrm{ml}$ (Fig. 3a) and also it supports the fungal growth (Fig. 3b).

\section{Quantification of cellulase by Fpase and CMCase assay}

The efficiency of isolated strain for producing cellulase was estimated by supplementing different carbon sources to the BSM. Endoglucanase activity was analysed by CMCase assay which showed a maximum activity of $0.25 \mathrm{U} / \mathrm{ml}$ (Fig. 4; Table 1) when supplemented with $1 \% \mathrm{CMC}$ as the carbon source. Here, CMC acts as an inducer for the production of endoglucanase (EG), whereas glucose and sucrose hindered the productivity. Almost similar activity was reported by some researchers (26); they got an enzyme activity of $0.92 \mathrm{U} / \mathrm{ml}$ by $A$. niger. Reports suggest that Trichoderma sp. exhibited (27) enzyme activity of $0.8 \mathrm{U} / \mathrm{ml}$ towards Fpase. A. flavus BS1 (28) was also able to produce endoglucanase with an activity of $2.793 \mathrm{U} / \mathrm{ml}$ on optimised carbon source, ie. 1\% CMC. The enzyme production (29) increased when the basal medium was supplemented with different substrates (carbon and nitrogen sources) and it showed highest activities of FPase $6.2 \mathrm{U} / \mathrm{ml}$ and CMCase $54.2 \mathrm{U} / \mathrm{ml}$ when lactose (1\%) and yeast cream (1\%) was supplemented into the basal medium. Substrate optimization may induce cellulase production. Supplementing substrate induced cellulase production when TKP (tamarind kennel powder) was added to the basal medium (30). Therefore, it may be possible to produce cellulase with the highest activity when the optimization process was done with several factors including both physiological and nutritional parameters. 


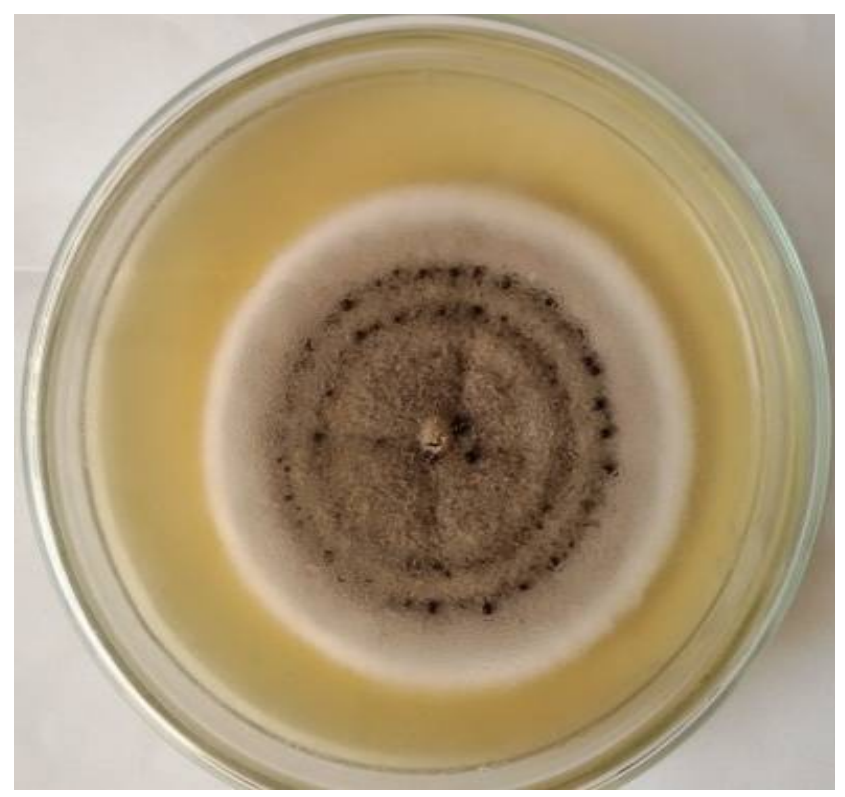

Fig. 1. Morphology of strain grown on SDA plates showing pigment production.

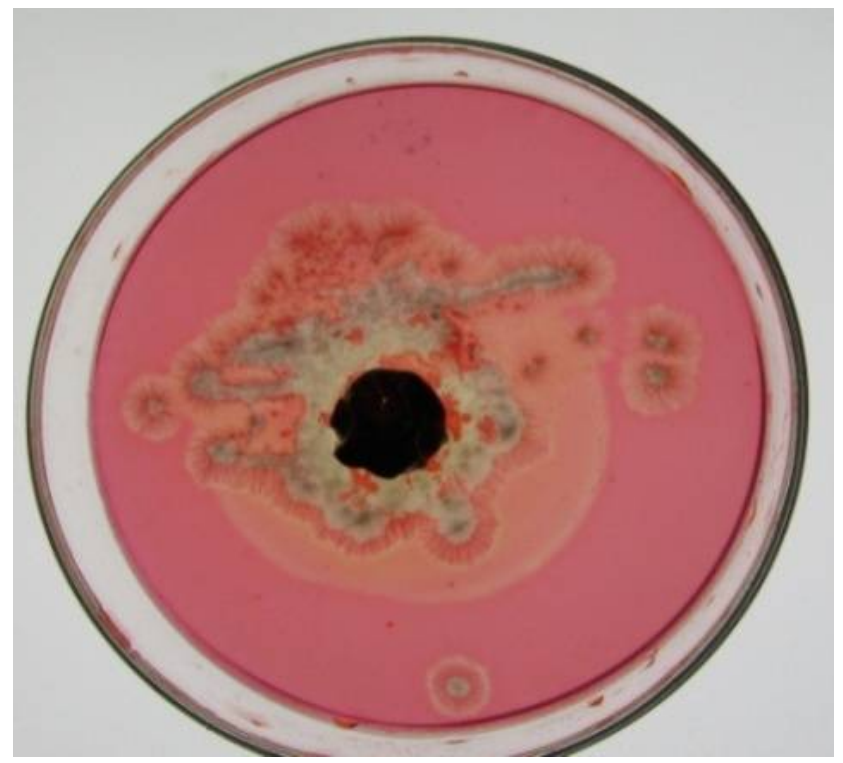

Fig. 2. Strain showing zone of hydrolysis around the inoculated fungal mycelia mat on $4^{\text {th }}$ day of inoculation (digital image canon powershots x $530 \mathrm{hs)}$.

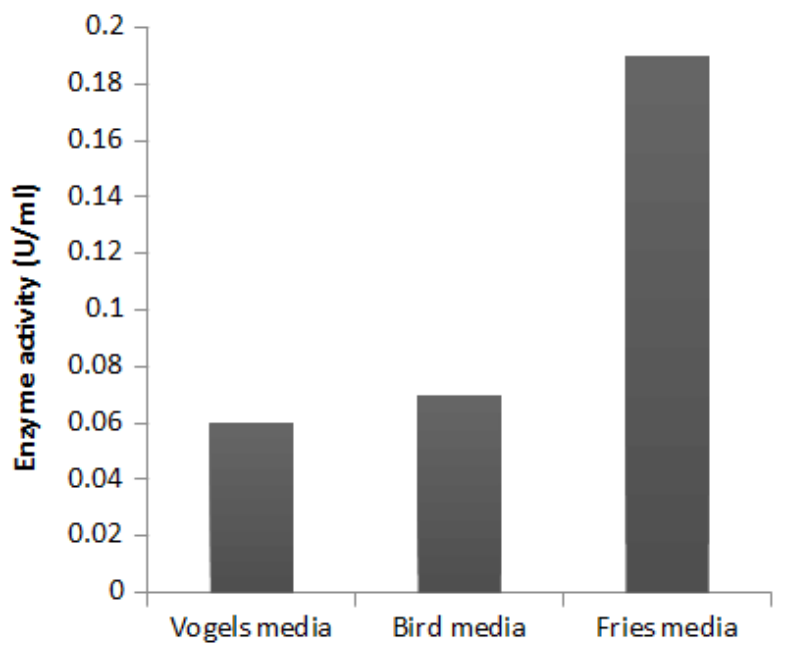

Fig. 3a. Comparison of cellulase producing media.

\section{Comparison of production of cellulase in organic and inorganic supplements}

One of the main objectives of the study was to compare the cellulase production in organic and inorganic substrates. The isolate was able to produce high titers of cellulase in the presence of inorganic

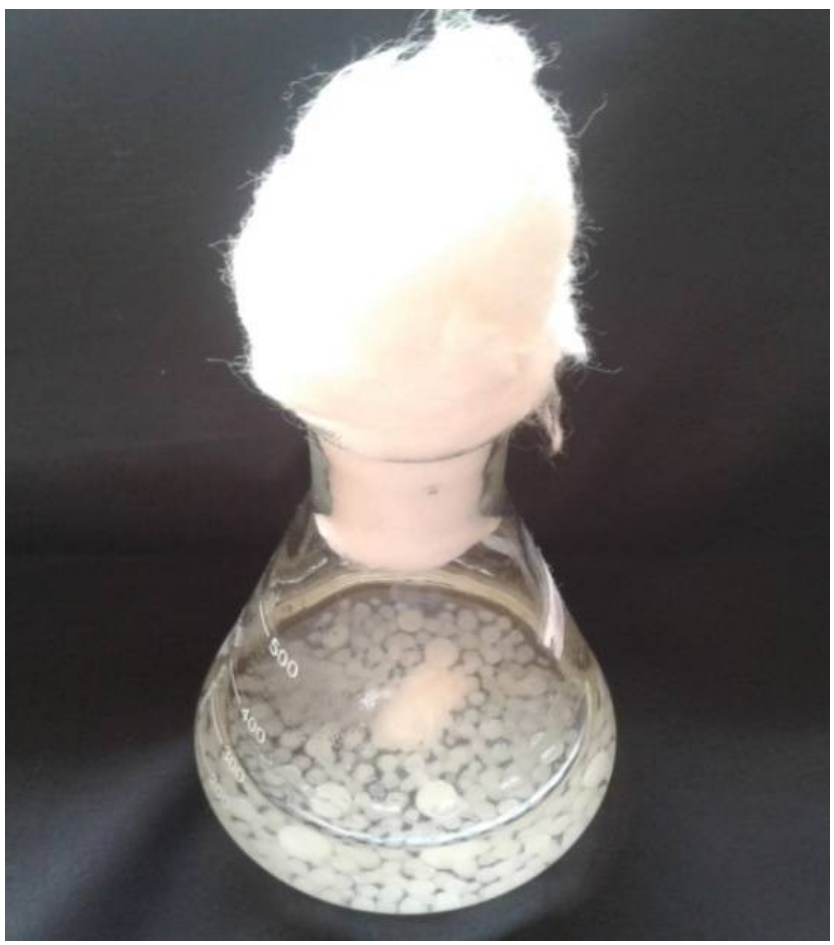

Fig. 3b. Showing the fungal growth on Basal mineral salt media (Fries medium).

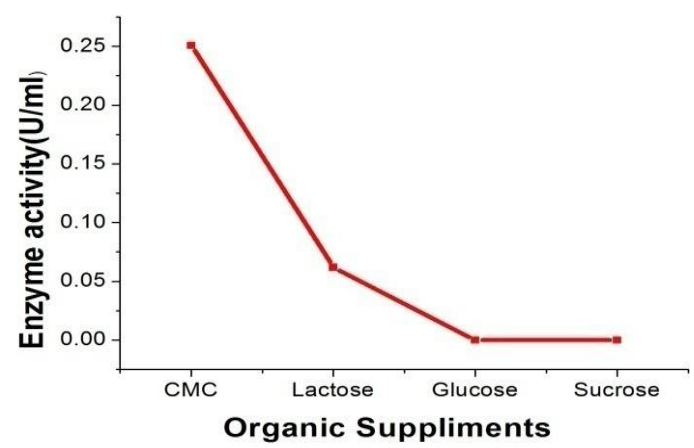

Fig. 4. Cellulase production profile of the strain by $1 \%$ of carbon source in SmF: maximum production of endoglucanase, when 1\% CMC was supplimeted to the Basal medium.

Table 1. Endoglucanase activity when BSM (Basal Mineral salt media) was supplemented with $1 \%$ of each inorganic supplements on SMF by the strain

\begin{tabular}{ccc}
\hline \multirow{2}{*}{ Media + inorganic supplements } & \multicolumn{2}{c}{ Enzymatic activity (U/ml) } \\
\cline { 2 - 3 } & CMCase & FPase \\
\hline BSM+CMC & 0.25 & ND \\
\hline BSM+Lactose & 0.05 & ND \\
\hline BSM+Glucose & 0.00 & ND \\
\hline BSM+Sucrose & 0.00 & ND \\
\hline
\end{tabular}

natural substrates; especially in SCB when compared to other inorganic supplements. SCB (5 g), when supplied with BSM (10 ml), produced cellulase of $8 \mathrm{IU} /$ 
g for FPase and $10.35 \mathrm{IU} / \mathrm{g}$ for endoglucanase (Fig. 5; Table 2). The unprocessed natural supplements used for Solid State Fermentation (SSF) were found to be utilised by the organism and in turn, they produce cellulase enzyme. Hydrolysing activity was quantified by both FPase and endoglucanase assays. Isolated strain efficiently hydrolyses all the four agricultural residues considered for the study. Of which, SCB was found to be an efficient substrate for

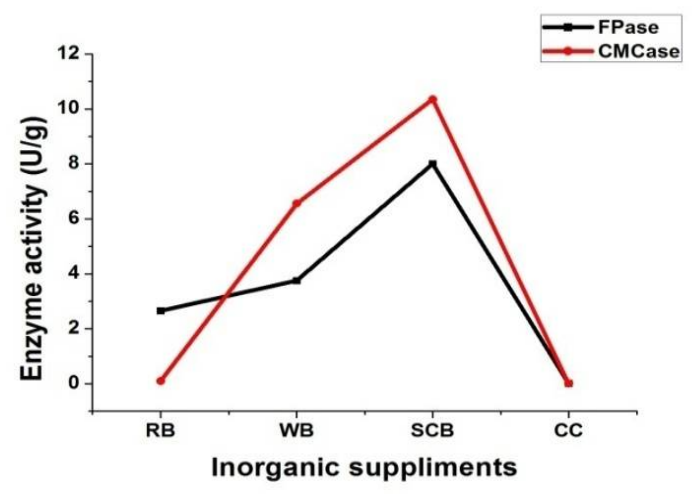

Fig. 5. Cellulase production profile of the strain by SSF: showing filter paper activity and endoglucanase activity (RB-Rice Bran, WBWheat Bran, SCB-Sugarcane Bagasse and CC-Coconut Cake).

Table 2. Endoglucanase activity and FPase activity from strain cultivated on organic supplements under SSF

\begin{tabular}{ccc}
\hline \multirow{2}{*}{ Media (10 ml)+ organic supplements } & \multicolumn{2}{c}{ Enzymatic activity (U/ml) } \\
\cline { 2 - 3 } & CMCase & FPase \\
\hline BSM+RB & 2.65 & 0.1 \\
\hline BSM+WB & 3.75 & 6.55 \\
\hline BSM+SCB & 8.00 & 10.35 \\
\hline BSM+CC & 0.00 & 0 \\
\hline
\end{tabular}

producing cellulase. This result is comparable with the results of an earlier work (31). Researchers are interested in SSF due to its lesser effluent generation, although it is an old technique. It was noted that Endoglucanase production increased along with a decrease in biomass (31). Cellulase could be better produced (16) using kinnow pulp as a major substrate (32). Demonstrated maximum production of cellulase from Trichoderma ressei ZU-02 using corn corb. All these reports suggest that SSF is a suitable method for the production of cellulase, compared to SMF. Also, it is evident that SSF is cost-effective than SMF and can produce in large amounts for industrial purposes.

\section{Optimisation of incubation time}

The culture filtrate subjected for enzymatic assay revealed that the optimum time for the production of cellulase was at $72 \mathrm{hr}$ with an activity of 0.25 $\mathrm{U} / \mathrm{ml}$. The strain was cultured on a basal medium that supported the growth as well as enzyme production and studied the endoglucanase production and total cellulase production by optimising incubation time and noted that total cellulase production was at $72 \mathrm{hr}$ and endoglucanase production at $168 \mathrm{hr}$ respectively (Fig. 6). Endoglucanase production (28) on the $5^{\text {th }}$ day of incubation was also explained. It was reported that (33) at $170 \mathrm{hr}$ cellulase production was found increased and the production decreased beyond that time. Some researchers described that the production of cellulase was found to be maximum after 4 days of incubation (34).

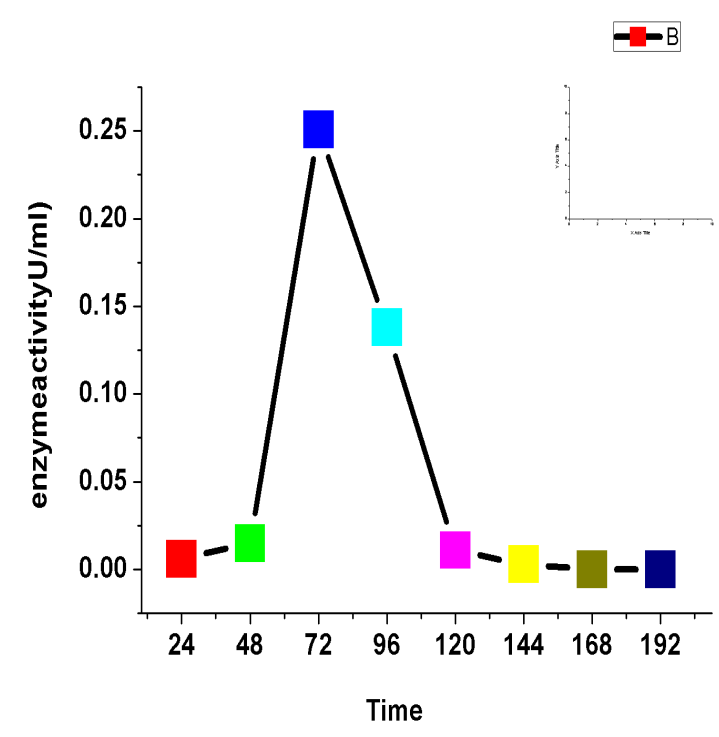

Fig. 6. Determination of optimum time for the enzyme production (B represents CMCase).

\section{Conclusion}

The intention of the study was to isolate a microbe which can actively hydrolyse the cellulose to produce value-added products including biofuels which has an increasing demand in the petroleum-fuel fields. In the study, the organism used is a fungus, which is cosmopolitan in distribution. Researchers can isolate and produce cellulase in a large scale by different fermentation methods by easily available raw materials without huge investment for the starting material. The study successfully demonstrated cellulase production from cheap raw materials.

As the role of cellulase is inevitable in the different industry, the need for exploration of novel organisms producing cellulase also gained attention. Moreover, the large scale production of cellulase will help to increase the annual turn over of our country.

\section{Acknowledgement}

VV thankfully acknowledge to University of Kerala for providing Junior Research Fellowship (No. ACE1/ A3/115/BTY/22279/2015-11) as financial assistance.

\section{Authors' contributions}

VV designed and conducted the experiment in the laboratory and written the manuscript. AJN supervised the work, corrected and submitted the manuscript. Both the authors read the manuscript before the final submission.

\section{Conflict of Interest}

Authors do not have any conflict of interest to declare. 


\section{References}

1. Hong J, Ye X, Zhang YH. Quantitative determination of cellulose accessibility to cellulase based on adsorption of a nonhydrolytic fusion protein containing CBM and GFP with its applications. Langmuir. 2007;23(25):12535-540. https://doi.org/10.1021/la7025686

2. Murai T, Ueda M, Kavaguchi T, Arai M, Tanaka M. Assimilation of cellooligosaccharides by a cell surface engineered yeast expressing $\beta$-glucosidase and carboxymethylcellulase from Aspergillus aculeatus. Appl Environ. Microbiol. 1998;64 (12):4857-61. https://doi.org/10.1128/AEM.64.12.4857-4861.1998

3. Sukumaran RK, Singhania RR, Pandey A. Microbial cellulases Production, applications and challenges. Journal of Scientific \& Industrial Research. 2005;64:832-44

4. Fayyaz UR, Mehwish AM, Ilyas T, Ashraf S, Amtul JS, Naima HN et al. Isolation of cellulolytic activities from Tribolium castaneum (red flour beetle) Agricultural and Biological Chemistry. 2009;8(23):6710-671

5. Akiba S, Kimura Y, Yamamoto K, Kumagai H. Purification and characterization of a protease-resistant cellulase from Aspergillus niger. J Ferment Bioeng. 1995;79:125-30. https://doi.org/10.1016/0922-338X(95)94078-6

6. Paice MG, Jurasek L. Removing hemicellulose from pulps by specific enzymic hydrolysis. J Wood Chem Tech. 1987;4:187-98. https://doi.org/10.1080/02773818408081152

7. Poutanen K. Enzymes: An important tool in the improvement of the quality of cereal foods. Trends in Food Science and Technology. 1997;8:300-06. https://doi.org/10.1016/S09242244(97)01063-7

8. Shikata S, Saeki K, Okoshi H, Yoshimatsu T, Ozaki K, Kawai S. Alkaline Cellulases for Laundry Detergents: Production by Alkalophilic Strains of Bacillus and Some Properties of the Crude Enzymes Agric. Biol. Chem. 1990;54(1):91-96 https://doi.org/10.1271/bbb1961.54.91

9. Ajoy KS, Nolan JE. Enzymatic Hydrolysis of Cotton Fibers Modeling Using an Empirical Equation. The Journal of Cotton Science. 2004;8:254-60.

10. Artur CP. Mechanism of action in textile process. Carbohydrate Polymers. 1998;37:273-77. https://doi.org/10.1016/S01448617(98)00070-8

11. Bajpai P. Application of enzymes in the pulp and paper industry. Biotechnology Progress. 1999;15:147-57. https://doi.org/10.1021/bp990013k

12. Bhat MK. Cellulases and related enzymes in biotechnology. Biotechnology Advances. 2000;18:355-83. https://doi.org/10.1016/S0734-9750(00)00041-0

13. Sadhu S, Maiti TK. Cellulase Production by Bacteria: A Review British Microbiology Research Journal. 2013;3(3):235-58. https://doi.org/10.9734/BMRJ/2013/2367

14. Miyamoto K, editor. Renewable biological systems for alternative sustainable energy production. Food \& Agriculture Org.; 1997

15. Rubia CGC, Sandro AR, Thatiane RM, JoaoLucio A, Joao AP, Cristina GM, et al. Endophytic fungi: expanding the arsenal of industrial enzyme producers. J Ind Microbiol Biotechnol. 2014; 41:1467-78. https://doi.org/10.1007/s10295-014-1496-2

16. Harinder SO, Yogita C, Sunil B, Gurpreet SD. Production of cellulases through solid state fermentation using kinnow pulp as a major substrate, Food Bioprocess Technol. 2010;3:528-36. https://doi.org/10.1007/s11947-008-0092-8

17. Saithong P, Panthavee W, Stonsavapak S, Congfa L. Isolation and Primary identification of endophytic fungi from Cephalotaxus mannii trees. Maejoint J Sci Technol. 2010;4(3);446-53
18. Pointing SB. Qualitative methods for the determination of lignocellulolytic enzyme production by tropical fungi. Fungal Diversity. 1999;2:17-33

19. Yeoh HH, Khew E, Lim G. A simple method for screening cellulolytic fungi. Mycologica. 1985;77:161-62. https://doi.org/10.1080/00275514.1985.12025077

20. Ghose TK. Measurement of cellulase activity. Pure and Applied Chemistry. https://doi.org/10.1351/pac198759020257

21. Alonso R, Tiscornia S, Alfenas AC, Bettucci L. Fungi associated to bark lesions of Eucalyptus globulus stems in plantations from Uruguay. R Árvore. 2009;33:(4)591-97. https://doi.org/10.1590/S0100-67622009000400001

22. Malcolm S, Cumbie R. Congo red as a fluorochrome for the rapid detection of fungi. Journal of Clinical Microbiology. 1988; 26(5):827-30. https://doi.org/10.1128/JCM.26.5.827-830.1988

23. Lillie RD. Diazo and polyazo dyes. In: EH Stotz, VM Emmel, editors. HJ Conn's biological stains. The Williams \& Wilkins Co. Baltimore; 1977. Vol. 9. pp. 147-48

24. Wood PJ, Fulcher RG. Interaction of some dyes with cereal glucans. Cereal Chem. 1978;55:952-66

25. Meddeb-Mouelhi F, Moisana JK, Beauregarda M. A comparison of plate assay methods for detecting extracellular cellulase and xylanase activity. Enzyme and Microbial Technology. 2014 66:16-19. https://doi.org/10.1016/j.enzmictec.2014.07.004

26. Uttam K, Tapwal A, Kalkal P, Varghese S, Chandra S. Isolation and screening of cellulase producing fungi from forest waste. International Journal of Pharmaceutical and Biological Archives. 2013;5(1):56-59

27. Om S, Shrivastava MK, Anoop B, Tripathi V, Gupta V, Kuldeep K. Production, Purification, Characterization and Application of Cellulase. Int J Pure App Biosci. 2014;2(4):222-39

28. Sajith S, Sreedevi S, Priji P, Unni KN, Benjamin S. Production and partial purification of cellulase from a novel fungus Aspergillus flavus BS1. Ann Microbiol. 2014;64:763-71. https://doi.org/10.1007/s13213-013-0711-0

29. Jun H, Bing Y, Keying Z, Xuemei D, Daiwen C. Strain improvement of Trichoderma reesei Rut C-30 for increased cellulase production. Indian J Microbiol. 2009;49:188-95. https://doi.org/10.1007/s12088-009-0030-0

30. Chatterjee R, Majumder K, Sengupta S. Tamarind kernel powder co-induces xylanase and cellulase production during submerged fermentation of Termitomyces clypeatus. Biotechnology and Bioprocess Engineering. 2010;15:854-61. https://doi.org/10.1007/s12257-009-3042-z

31. Muhammad S, Aqeel A, Shakeel AK. Production of cellulase from Aspergillus terreus MS105 on crude and commercially $\begin{array}{lll}\text { purified } & \text { 3Biotech. 2016;6:103. }\end{array}$ https://doi.org/10.1007/s13205-016-0420-Z

32. Xia L, Cen P. Cellulase production by solid state fermentation on lignocellulosic waste from the xylose industry. Process Bichem. https://doi.org/10.1016/S0032-9592(99)00015-1

$1999 ; 34: 909-12$

33. Sanjay KHK, Sharma B, Sarkar C. Effect of substrate and fermentation conditions on pectinase and cellulase production by Aspergillus niger NCIM 548 in Submerged (SmF) and Solid State Fermentation (SSF). Food Sci Biotechnol. 2011;20(5) 1289-98. https://doi.org/10.1007/s10068-011-0178-3

34. Sherief AA, El-Tanash AB, Atia N. Cellulase production by Aspergillus fumigatus grown on mixed substrate of rice straw and wheat bran. Research Journal of Microbiology. 2010;5(3):199-211. https://doi.org/10.3923/jm.2010.199.211 